\title{
THE EFFECTS OF FORMALDEHYDE ON THE BRAIN OF THE ALBINO RAT
}

\author{
HELEN DEAN KING
}

The Wistar Institute of Anatomy and Biology

TEN CHARTS

Although formaldehyde was discovered in 1863, it wais not until thirty years later that Blum ('93) and Hermann ('93), working independently, found that an aqueous solution of this substance is an excellent medium for preserving and hardening various animal tissues. Owing to its many admirable properties and to its relative cheapness, 'formalin' (a commercial 40 per cent solution of formaldehyde) soon became extensively employed as a fixing and preserving reagent for entire brains as well as for other large pieces of tissue, being used either in a 5 to 15 per cent aqueous solution or combined with other substances such as alcohol, alum or salt.

In an extensive series of experiments dealing with the effects of various formalin solutions on the weight of the brains of man, of sheep and of various other mammals, Hrdlicka ('06) showed that the size of the brain, the age of the animal from which the brain was taken and the strength of the solution used were all factors that influenced the weight and volume changes in the brain to a very considerable extent. Hrdlicka did not, however, ascertain the relative importance of these various factors, nor did he make any study of the histological effects produced in the brain tissue by formaldehyde solutions. At the present time formalin is commonly used in laboratories and museums as a fixative and also as a preservative for the brains of man and of other mammals. It has seemed worth while, therefore, to make a careful study of the changes produced by this substance, acting under different conditions, on a series of brains from animals of known ages from birth to maturity. Experiments of this kind 
ought to define the limits of the use of formalin as a brain preservative and to indicate when and how this substance can be used to the greatest advantage in neurological work. The present paper records the results of such a series of experiments made on brains of the albino rat (Mus norvegicus albinus). As a 4 per cent solution of formaldehyde ( 10 per cent formalin) is the one that the experience of many investigators has shown is the best for brain preservation as well as for general histological work, a solution of this strength was the only one used in this series of investigations.

The technique employed in all the experiments was as follows: Animals of known ages were killed with ether, and their body lengths and body weights recorded. The brain, with its meninges intact, was removed as soon as possible after the death of the animal, being cut from the cord at the tip of the calamus scriptorius. Each brain was then weighed to a tenth of a milligram in a closed weighing bottle and placed on absorbent cotton in a definite amount of 4 per cent formaldehyde. The glass stoppered bottles in which the brains were kept were of uniform size, and they were inclosed in black covered cases to exclude light as, according to Fish ('95), this precaution will prevent the decomposition of the solution and the subsequent formation of paraformaldehyde. The brains were weighed at definite times which varied somewhat in different series of experiments. On removal from the solution the brain was placed for a moment on filter paper to remove the superfluous liquid, it was then weighed as quickly as possible in a closed weighing bottle and returned to the solution After a final weighing at the end of a stated period, the brains were dried for one week in a water bath which had a temperature of about $95^{\circ} \mathrm{C}$. They were then cooled in a desiccator and reweighed in order to determine the effects of the solution on the percentage of solids in the brains. In some few cases, after the final weighing, brains were transferred into alcohol, imbedded by the celloidin-paraffine method of Bodecker ('08), and then sectioned and stained with thionin in order to ascertain the histological effects that had been produced. 
THE WEIGHT CHANGES PRODUCED BY FORMALDEHYDE IN BRAINS OF ALBINO RATS OF KNOWN AGES

Series 1 This was a preliminary set of experiments made to discover the general effects of a 4 per cent solution of formaldehyde on the brains of rats of different ages. In these experiments brains were taken from animals of the following ages: newborn, 10, 20, 40, 50, 70 days and adults, approximately 200 days old. Three rats of each age were used, animals of a given age being taken from the same litter except in the case of adult rats which were of unknown parentage and therefore may or may not have belonged to the same litter. As it was not possible to obtain all the rats wanted for the experiments at one time, the initial weighing of the first lot of brains was made early in October, 1910, while the final lot of material was not obtained until February, 1911. Each brain was put into $40 \mathrm{cc}$. of a 4 per cent solution of formaldehyde that was neutralized with $\mathrm{NaCO}_{3}$. The solution of formaldehyde used was, in some cases, one that had been made up for some weeks; in other cases a fresh solution was made as wanted, either from formalin that had been in the laboratory for some time or from a newly purchased supply. The age of the solution or the condition of the formalin used in making the solution were factors that were not thought to be of importance and therefore no attention was paid to them.

The different lots of brains were weighed at irregular intervals during the first week they were in the solution, then every seven days for nine weeks. At the end of this time each brain was transferred into a fresh solution, made at the time it was wanted for use. The bottles containing the brains were then sealed with paraffine and kept for two months at laboratory temperature. After eighteen weeks the brains received their final weighing and they were then dried to obtain the percentage of solids. In each set of brains of the same age the individual weighings were very uniform, as they showed a difference of only 2 or 3 per cent in the majority of cases. These differences can undoubtedly be ascribed to the fact that animals taken from the same litter often vary considerably in size even when they are of the same 
sex, and with this difference in size is found a corresponding difference in brain weight since, as shown by Donaldson ('09), the size of the brain is correlated with the size of the animal, not with its age.

The times when the various weighings were made in this series of experiments, together with the average percentage weight increase for each group of three brains are given in table 1 .

TABLE 1

Percentage weight increase in rats' brains kept for eighteen weeks in a stock solution of 4 per cent formaldehyde neutralized with $\mathrm{NaCO}_{3}$ (averages for three brains at each age)

\begin{tabular}{|c|c|c|c|c|c|c|c|}
\hline \multirow[b]{2}{*}{ TIME SOLUTION ACTED } & \multicolumn{7}{|c|}{ AGE OF RATS } \\
\hline & $\begin{array}{l}\text { New- } \\
\text { born }\end{array}$ & $\begin{array}{c}10 \\
\text { days }\end{array}$ & $\stackrel{20}{\text { days }}$ & $\begin{array}{c}40 \\
\text { days }\end{array}$ & $\begin{array}{c}50 \\
\text { days }\end{array}$ & $\begin{array}{c}70 \\
\text { days }\end{array}$ & $\begin{array}{l}200 \\
\text { days }\end{array}$ \\
\hline 1 day..... & 21.6 & 30.0 & 28.5 & & 25.8 & & \\
\hline 2 days. . & 24.3 & & 29.6 & & & & \\
\hline 3 days. . & 26.7 & & & & & & \\
\hline 4 days.... & $27.0^{1}$ & & & & 26.7 & & \\
\hline 5 days $\ldots \ldots \ldots \ldots \ldots$ & & 31.5 & & & & & \\
\hline 7 days $\ldots \ldots \ldots$ & 23.4 & 33.11 & $29.9^{1}$ & $53.5^{1}$ & $27.8^{1}$ & 40.9 & 35.8 \\
\hline 8 days.......... & & 32.4 & 28.9 & & 27.0 & & \\
\hline 9 days.... & & & 28.3 & & 25.4 & & \\
\hline 2 weeks... & 21.7 & 29.0 & 28.9 & 51.9 & 25.3 & 41.7 & $40.8^{1}$ \\
\hline 3 weeks.... & 20.9 & 27.2 & 28.4 & 48.0 & 25.2 & 42.9 & 40.7 \\
\hline 4 weeks. . & 18.9 & 30.1 & 28.0 & 47.8 & 24.9 & 44.2 & 39.6 \\
\hline 5 weeks. . & 17.4 & 27.7 & 28.7 & 48.2 & 25.1 & 44.4 & 38.5 \\
\hline 6 weeks. . & 15.4 & 29.4 & 27.9 & 46.7 & 24.3 & 44.9 & 38.0 \\
\hline 7 weeks.. & 16.1 & 29.9 & 28.0 & 46.1 & 25.1 & $45.4^{1}$ & 39.8 \\
\hline 8 weeks. . & 15.2 & 28.7 & 27.7 & 47.0 & 24.9 & 44.8 & 39.8 \\
\hline 9 weeks.. & 14.5 & 28.3 & 27.0 & 47.0 & 25.0 & 44.1 & 40.6 \\
\hline 10 weeks. . & 15.1 & 27.1 & 27.6 & 46.4 & 25.4 & 43.8 & 40.3 \\
\hline 18 weeks..... & 12.7 & 24.1 & 24.7 & 40.0 & 21.6 & 37.6 & 33.5 \\
\hline Average percentage gain. & 19.4 & 29.2 & 28.2 & 47.5 & 25.3 & 43.2 & 38.9 \\
\hline
\end{tabular}

' Maximum weight increase.

The results of this series of experiments show that a 4 per cent solution of formaldehyde causes a pronounced swelling in the brains of rats of all ages. The maximum weight increase is reached, in most cases, during the first week, and there is then 
a gradual decrease in weight until, after the brains have been in the solution for eighteen weeks, the percentage weight increase is reduced from 5 to 15 per cent below the maximum. In general, as shown in table 1 , the amount of swelling seems to increase with the age of the rat up to the forty-day perind, then it decreases slowly. Under the conditions of the experiments, therefore, the amount of swelling is not directly proportional either to the age of the animal or to the size of the brain.

Chart 1 shows the graph for the final percentage weight increase in the various sets of brains at the end of eighteen weeks.

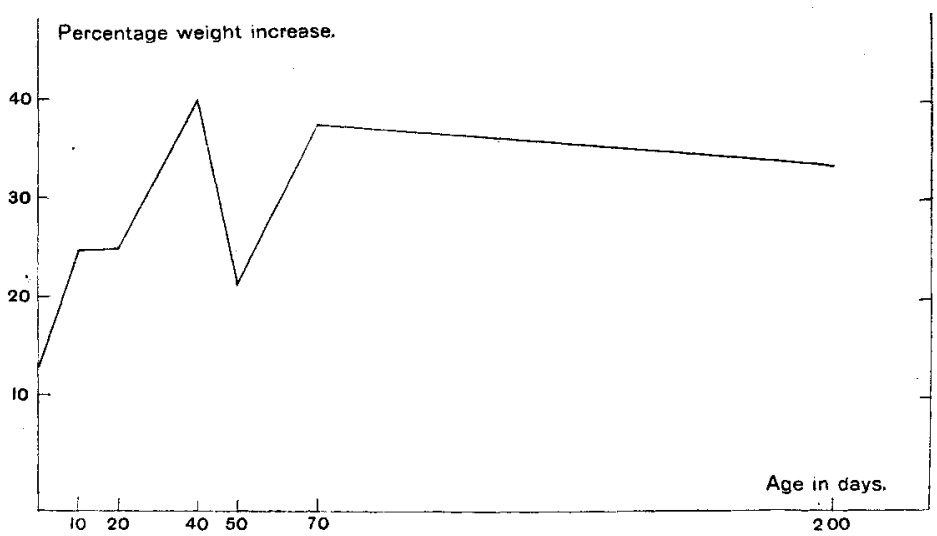

Chart 1 Showing the final percentage weight increase in a series of rats' brains kept for eighteen weeks in stock solutions of 4 per cent formaldehyde.

Starting relatively low the graph reaches its highest point with the forty-day group. Then comes a decided drop at fifty days, followed by a sharp rise at seventy days and a slight falling at the adult stage. As all the brains were kept in the same amount of solution under similar conditions of light and of temperature, the fall in the graph at the fifty-day period seems explicable only on the assumption that the stock solution of formaldehyde used in this instance had undergone some chemical change which had lessened its swelling action on the brain tissue.

As the stock solutions of 4 per cent formaldehyde used in this series of experiments had been kept in the laboratory for vary- 
ing lengths of time, it seemed possible that the age of the solution might be a factor that would appreciably affect its swelling action on brain tissue. To test this assumption the following series of experiments was made.

Series 2. In this series, and in all others that were made subsequently, brains from rats of the following ages were used: newborn, 10, 20, 40, 50, 70, 100 and approximately 200 days old. Six rats of each age were used, the animals being taken from the same litter in order to avoid any possible variation in brain structure that might be characteristic of different litters. Three brains of each age were placed in a neutralized solution of 4 per cent formaldehyde that had been standing for five months; the remaining three brains of the same age were put into a neutralized solution that was made when the experiments were started. As all the animals were killed within a period of two weeks, the second solution was comparatively fresh when used on the final set of brains.

Each brain was put into 40 ec. of the solution and kept at laboratory temperature. The weighings were made on the first, third, and seventh days of preservation, also at the end of the second, third and tenth weeks. The specimens were then heat dried for one week and again weighed in order that the percentage of solids might be obtained.

Table 2 gives the data for the brains kept in the 'old' solution.

The data obtained in the experiments in which the brains were kept in the freshly made solution are given in table 3.

The results of these experiments are much more uniform than those obtained in the first series. The maximum amount of swelling was reached in all brains by the third day, and then there was a very gradual decline in weight until, at the end of ten weeks, the percentage weight increase was from 1 to 12 per cent below the maximum; in both sets of experiments the greatest loss in weight took place in the brains of new-born rats.

If we compare the data in table 2 with that in table 3 , it is seen that the age of the solution used has a very marked effect on the amount of swelling in the brains at all ages. The old 
TABLE 2

Percentage weight increase in rats' brains, each kept for ten weeks in 40 cc. of a neutralized solution of 4 per cent formaldehyde made five months before the experiments began (averages for three brains at each age)

\begin{tabular}{|c|c|c|c|c|c|c|c|c|}
\hline \multirow[b]{2}{*}{ TIME SOLUTION ACTED } & \multicolumn{8}{|c|}{ AGE OF RATS } \\
\hline & $\begin{array}{l}\text { New- } \\
\text { born }\end{array}$ & $\begin{array}{c}10 \\
\text { days }\end{array}$ & $\begin{array}{c}20 \\
\text { days }\end{array}$ & $\begin{array}{c}40 \\
\text { days }\end{array}$ & $\begin{array}{c}50 \\
\text { days }\end{array}$ & $\begin{array}{c}70 \\
\text { days }\end{array}$ & $\begin{array}{c}100 \\
\text { days }\end{array}$ & $\begin{array}{c}200 \\
\text { days }\end{array}$ \\
\hline 1 day ..... & $29.7^{1}$ & 28.8 & 25.0 & 25.2 & 26.91 & 24.5 & $28.3^{1}$ & 15.3 \\
\hline 3 days $\ldots$ & 28.0 & $35.0^{1}$ & $28.3^{1}$ & $26.3^{1}$ & 26.8 & $27.3^{1}$ & 26.8 & $21.0^{1}$ \\
\hline 7 days & 27.3 & 33.0 & 27.3 & 25.0 & 25.1 & 25.1 & 25.7 & 18.6 \\
\hline 2 weeks & 23.9 & 31.9 & 27.3 & 24.5 & 25.1 & 25.3 & 26.3 & 18.9 \\
\hline 3 weeks.. & 23.4 & 31.4 & 28.3 & 24.9 & 25.5 & 24.4 & 25.3 & 19.3 \\
\hline 4 weeks... & 22.5 & 30.5 & 26.7 & 24.5 & 24.8 & 25.6 & 26.2 & 19.4 \\
\hline 10 weeks ....... & 17.6 & 27.9 & 26.9 & 24.7 & 25.2 & 25.6 & 25.0 & 19.2 \\
\hline Average percentage gain & 24.6 & 31.2 & 27.1 & 25.0 & 25.6 & 25.4 & 26.2 & 18.8 \\
\hline
\end{tabular}

1 Maximum weight increase

TABLE 3

Percentage weight increase in rats' brains, each kept for ten weeks in 40 cc. of a neutralized solution of 4 per cent formaldehyde made at the time the experiments began (averages for three brains at each age)

\begin{tabular}{|c|c|c|c|c|c|c|c|c|}
\hline \multirow{2}{*}{ TIME SOLCTION ACTED } & \multicolumn{8}{|c|}{ AGE OF RATS } \\
\hline & $\begin{array}{l}\text { New- } \\
\text { born }\end{array}$ & $\begin{array}{c}10 \\
\text { days }\end{array}$ & $\begin{array}{c}20 \\
\text { days }\end{array}$ & $\begin{array}{c}40 \\
\text { days }\end{array}$ & $\begin{array}{c}50 \\
\text { days }\end{array}$ & $\begin{array}{c}70 \\
\text { days }\end{array}$ & $\begin{array}{c}100 \\
\text { days }\end{array}$ & $\begin{array}{c}200 \\
\text { days }\end{array}$ \\
\hline $1 \mathrm{day}$. & $44.4^{1}$ & 58.2 & 39.5 & $37.9^{1}$ & $39.3^{1}$ & 34.4 & $45.6^{1}$ & 32.4 \\
\hline 3 days. & 42.0 & $64.6^{1}$ & $41.5^{1}$ & 37.6 & 38.5 & $38.6^{1}$ & 43.1 & $34.7^{1}$ \\
\hline 7 days.... & 41.5 & 62.1 & 40.1 & 36.4 & 35.6 & 34.1 & 41.1 & 30.9 \\
\hline 2 weeks... & 38.0 & 62.9 & 39.7 & 35.9 & 36.1 & 34.9 & 41.0 & 30.8 \\
\hline 3 weeks. . & 37.7 & 63.4 & 40.0 & 35.7 & 36.9 & 34.3 & 40.4 & 31.2 \\
\hline 4 weeks. . & 36.1 & 62.8 & 39.9 & 35.5 & 35.4 & 35.7 & 40.5 & 31.6 \\
\hline 10 weeks... & 33.9 & 61.4 & 39.4 & 35.5 & 36.1 & 35.5 & 37.7 & 31.8 \\
\hline Average percentage gain. & 39.1 & 62.2 & 40.0 & 36.4 & 36.7 & 35.4 & 41.3 & 31.9 \\
\hline
\end{tabular}

1 Maximum weight increase. 
solution causes less swelling in every case than the one that was comparatively fresh when used, the difference between the average percentage weight increase in the various sets of brains of like ages ranging from 10 to 31 per cent.

The final percentage weight increase in each set of brains at the end of ten weeks is shown graphically in chart 2 . The general form of the graphs is much the same, yet the graph for the

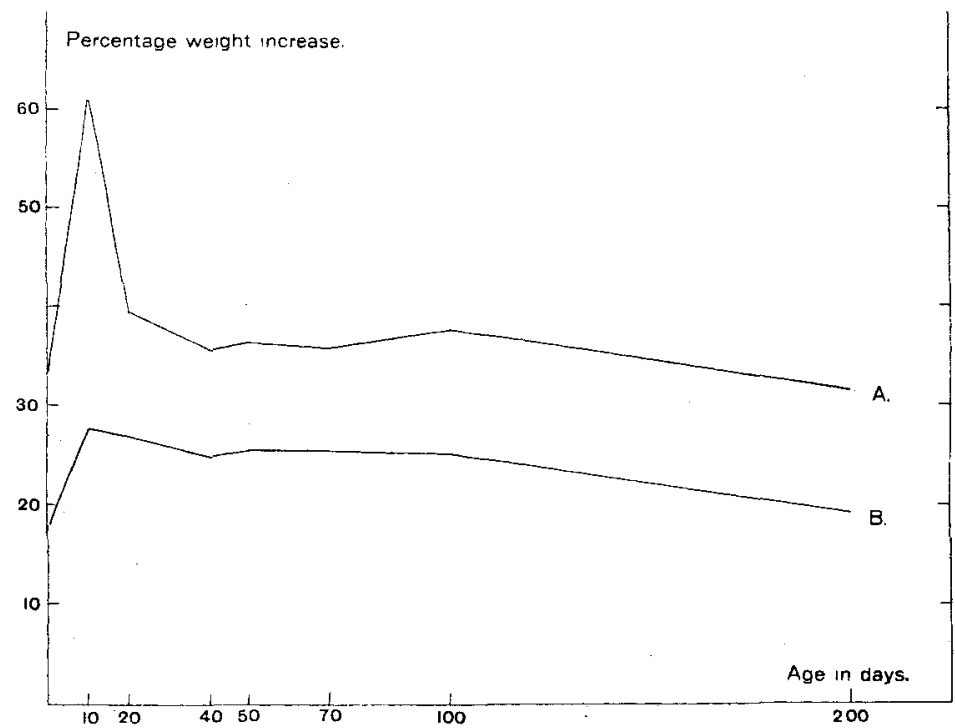

Chart 2 Showing the final percentage weight increase in two series of rats' brains, each kept for ten weeks in a neutralized solution of 4 per cent formaldehyde. $A$, solution made when the experiments began; $B$, solution five months old when used.

brains kept in the old solution (B) is much lower at every point than that for the brains kept in the freshly made solution (A).

The marked difference in the effects of these two solutions is not due to the fact that the older solution had become acid by standing while the newer solution had remained neutral. Both solutions were tested with good litmus paper on December 15, 1911, and each was found to give a very slight alkaline reaction. Since solutions of formaldehyde are readily decomposed it is prob- 
able that the older solution underwent some chemical change through standing. There was. however, no evidence of the formation of paraformaldehyde when the bottle containing the old solution was first opened; the liquid appeared perfectly clear and had the characteristic odor of formaldehyde. No analysis of the solution was made, so it is not possible to state just what changes had occurred in it.

The results of this series of experiments indicate unmistakably that the age of the animal is an important factor in determining the amount of swelling that the brain will undergo in 4 per cent formaldehyde. In general, the younger brains absorb a relatively greater amount of liquid than do the older ones. This result, which accords with the observations of Hrdlicka and of Donaldson ('94), can doubtless be ascribed, in part at least, to the fact that the brains of yound rats contain normally a greater percentage of water than do the older ones (Donaldson '10). According to the observations of Watson ('03) medullation in the rat's brain does not begin until the eleventh day after birth. The non-medullation of the fibers and the deficiency in supporting tissue are also factors that in all probability tend to increase the amount of swelling in the young brains.

Series 3. These experiments were made to ascertain whether the amount of swelling in the brain placed in 4 per cent formaldehyde will be influenced by the neutralization or by the nonneutralization of the solution. Lee ('05) does not approve of the neutralization of formaldehyde solutions, and he states that the slightly acid reaction that is usually found "is, as a rule, an advantage;" Bayon ('05), on the other hand, believes that an acid solution of formaldehyde is injurious to nerve tissue, and he advises that all such solutions should be neutralized with $\mathrm{NaCO}_{3}$. In carrying out these experiments it was considered necessary that the age of the solution should not be a factor that could influence the results, and, therefore, a fresh solution was made from a common stock supply of formalin when each lot of animals was killed. The four rats of each age that were used were taken from the same litter. Two brains from each group were put into $40 \mathrm{cc}$. of a solution neutralized with $\mathrm{NaCO}_{3}$; 
the two other brains of the group were put into the same amount of solution which was not neutralized and which gave a faintly acid reaction when tested with litmus paper. As the second series of experiments had shown that there is comparatively little difference between the percentage weight increase in the various sets of brains at the end of four weeks and at the end of ten weeks, these experiments and all the later ones were terminated at the end of one month and the brains heat dried.

Table 4 shows the data obtained in the experiments in which the brains were subjected to the action of a neutralized solution.

TABLE 4

Percentage weight increase in rats' brains, each kept for four weeks in 40 cc. of a neutralized solution of 4 per cent formaldehyde made fresh for each lot of animals killed (averages for two brains at each age)

\begin{tabular}{|c|c|c|c|c|c|c|c|c|}
\hline \multirow{2}{*}{ TIMX SOLUTION ACTED } & \multicolumn{8}{|c|}{ AGE OF RATS } \\
\hline & $\begin{array}{l}\text { New- } \\
\text { born }\end{array}$ & $\begin{array}{c}10 \\
\text { days }\end{array}$ & $\begin{array}{c}20 \\
\text { days }\end{array}$ & $\begin{array}{c}40 \\
\text { days }\end{array}$ & $\begin{array}{c}50 \\
\text { days }\end{array}$ & $\begin{array}{c}70 \\
\text { days }\end{array}$ & $\begin{array}{c}100 \\
\text { days }\end{array}$ & $\begin{array}{c}200 \\
\text { days }\end{array}$ \\
\hline 1 day........ & 60.4 & 54.7 & 45.8 & $47.6^{1}$ & $50.4^{1}$ & 44.9 & $44.2^{1}$ & 36.1 \\
\hline 3 days... & $65.8^{1}$ & $58.5^{1}$ & $52.9^{1}$ & 47.4 & 47.7 & $48.8^{1}$ & 42.7 & $40.1^{1}$ \\
\hline 7 days.... & 65.4 & 58.5 & 48.3 & 45.6 & 45.1 & 44.2 & 38.3 & 36.2 \\
\hline 2 weeks. & 65.1 & 58.4 & 48.9 & 45.3 & 44.8 & 43.2 & 38.6 & 33.0 \\
\hline 3 weeks. & 64.8 & 58.2 & 48.9 & 44.7 & 45.2 & 43.9 & 38.8 & 34.7 \\
\hline 4 weeks. . & 61.7 & 57.8 & 50.4 & 45.1 & 45.4 & 44.9 & 39.3 & 34.9 \\
\hline Average percentage gain..... & 63.4 & 57.7 & 49.2 & 45.9 & 46.4 & 44.8 & 40.3 & 35.8 \\
\hline
\end{tabular}

${ }^{1}$ Maximum weight increase.

The data given in this table indicate that, under the conditions of these experiments, the amount of swelling which the brains undergo diminishes as the age of the animal increases. Brains of new-born rats swell enormously, the average percentage increase in three days, when the maximum is reached, being 65.8 per cent of the original brain weight, and there is a falling off of only 4 per cent at the end of four weeks. Brains of tenday-old animals gain, on an average, only about 6 per cent less 
than those of the new-born: those belonging to the $20,40,50$ and 70-day groups swell nearly the same amount, showing a maximum weight increase of from 49 to 53 per cent. In older animals the maximum increase in weight is somewhat less, amounting to 44 per cent in the case of 100-day animals and 40 per cent in the adults. The weight changes for each set of brains during the four weeks the experiments were continued are shown in the series of graphs in chart 3.

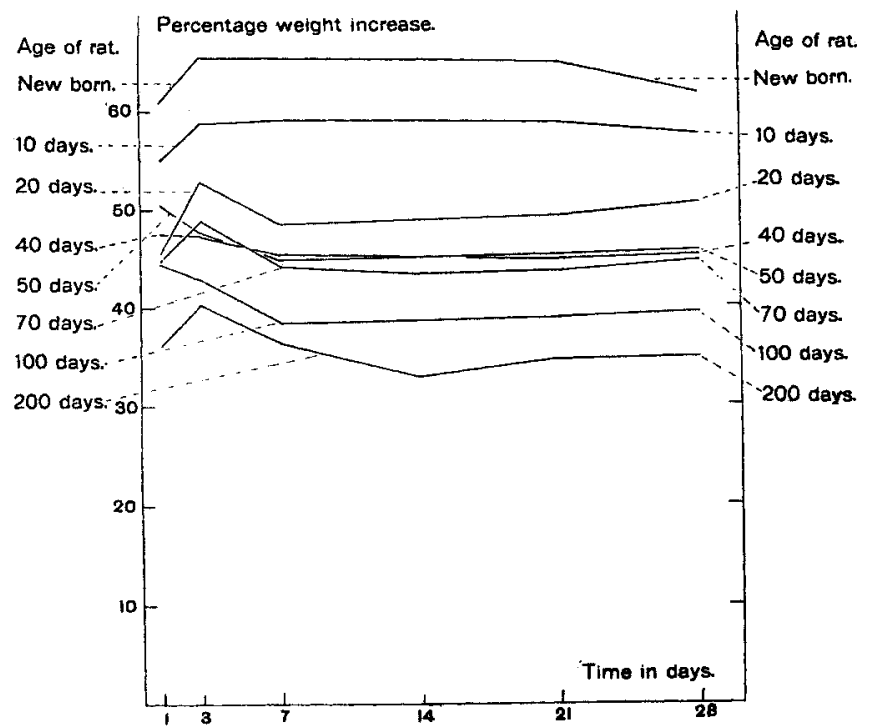

Chart 3 Showing the weight changes in brains of rats of various ages, each kept for four weeks in $\mathbf{4 0} \mathrm{cc}$. of a 4 per cent solution of formaldehyde neutralized with $\mathrm{NaCO}_{3}$.

As presumably all the solutions used in this set of experiments had the same chemical composition, the variations in the amount of swelling in the different groups of brains can doubtless be attributed to a difference in the chemical composition of the brains at different ages. The size of the brain, as will be shown later, is not a factor that influences the amount of swelling to any considerable extent. 
The data obtained when brains were kept in a non-neutralized solution of 4 per cent formaldehyde for four weeks are given in table 5 .

TABLE 5

Percentage weight increase in rats' brains, each kept for four weeks in $40 \mathrm{cc}$. of a non-neutralized solution of 4 per cent formaldehyde made fresh for each lot of animals killed (averages for two brains at each age)

\begin{tabular}{|c|c|c|c|c|c|c|c|c|}
\hline \multirow{2}{*}{ TIME BOLUTION ACTED } & \multicolumn{8}{|c|}{ AGE OF RATS } \\
\hline & $\begin{array}{l}\text { New- } \\
\text { born }\end{array}$ & $\begin{array}{c}10 \\
\text { days }\end{array}$ & $\stackrel{20}{\text { days }}$ & $\begin{array}{c}40 \\
\text { days }\end{array}$ & $\begin{array}{c}50 \\
\text { days }\end{array}$ & $\begin{array}{c}70 \\
\text { days }\end{array}$ & $\begin{array}{c}100 \\
\text { days }\end{array}$ & $\underset{\text { days }}{200}$ \\
\hline 1 day. & $34.5^{1}$ & 37.3 & 36.7 & 39.71 & $44.2^{1}$ & 39.5 & $41: 11$ & 32.2 \\
\hline 3 days. & 18.6 & 45.11 & 45.41 & 39.1 & 42.8 & $42.3^{1}$ & 39.4 & $35.4^{1}$ \\
\hline 7 days.... & 9.9 & 37.8 & 38.2 & 35.6 & 38.1 & 34.3 & 33.8 & 30.2 \\
\hline 2 weeks. & 3.5 & 30.4 & 34.6 & 31.5 & 32.6 & 31.5 & 29.0 & 26.7 \\
\hline 3 weeks. . & 0.4 & 25.9 & 30.7 & 28.3 & 30.6 & 29.5 & 27.4 & 24.5 \\
\hline 4 weeks... & -1.5 & 23.5 & 27.9 & 26.6 & 27.8 & 27.3 & 24.3 & 24.5 \\
\hline Average percentage gain.... & 13.1 & 33.3 & 35.6 & 33.5 & 36.0 & 34.1 & 32.5 & 28.9 \\
\hline
\end{tabular}

${ }^{1}$ Maximum weight increase.

As shown in the table, the effects of an acid solution of formaldehyde on the brain of a new-born rat is most remarkable. The maximum weight increase amounts to only 34.5 per cent of the original brain weight, and it is attained at the end of the first day. There is then a rapid decrease in weight with each succeeding weighing until, at the end of four weeks, the brain actually weighs 1.5 per cent less than the original weight: this indicates that the solution has extracted some substance from the brain tissue. In both the brains of this age used the percentage weight changes were practically the same, as there was a difference between them of less than 2 per cent at any weighing.

Brains of ten-day-old rats do not show such remarkable weight changes as do those of new-born animals. In fact, an acid solution of 4 per cent formaldehyde causes nearly the same amount of swelling in brains of all ages from ten days to maturity, there being a difference of less than 10 per cent between the maximum weight increase in any two sets of brains, and a difference of 
less than 5 per cent between the final weights. The very great difference between the effects of the solution on the brains of new-born animals and those on the brains of other ages is brought out very clearly in the graphs in chart 4 which show the percentage weight changes for each set of brains during the four weeks the experiments were continued.

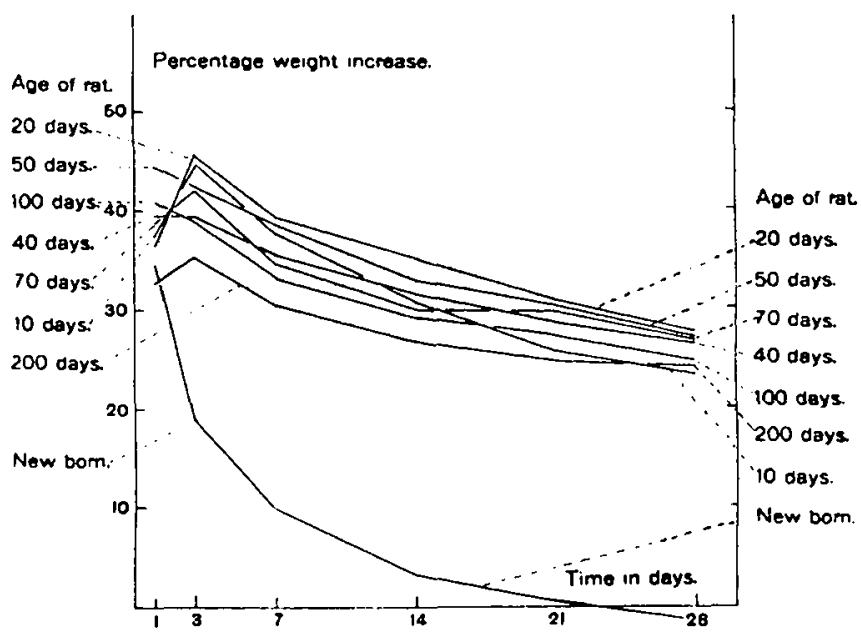

Chart 4 Showing the weight changes in brains of rats of various ages, each kept for 4 weeks in 40 cc. of a non-neutralized solution of 4 per cent formaldehyde.

This series of experiments shows that the neutralization or nonneutralization of a 4 per cent solution of formaldehyde has a marked effect on the amount of swelling of the brain tissue. The difference is shown in the graphs $A$ and $B$ of chart 5 which are plotted from the final percentage weight increase in the various sets of brains. As the weight of the brains of the new-born rats kept in the neutralized solution is some 62 per cent greater than that of the brains of the same age treated with the acid solution, the two graphs are very far apart at their beginning. At the ten-day period the difference between the graphs is reduced nearly one-half. They then approach gradually, and at the end are comparatively close together as the final weighings of the two sets of adult brains differed by only 10 per cent. 


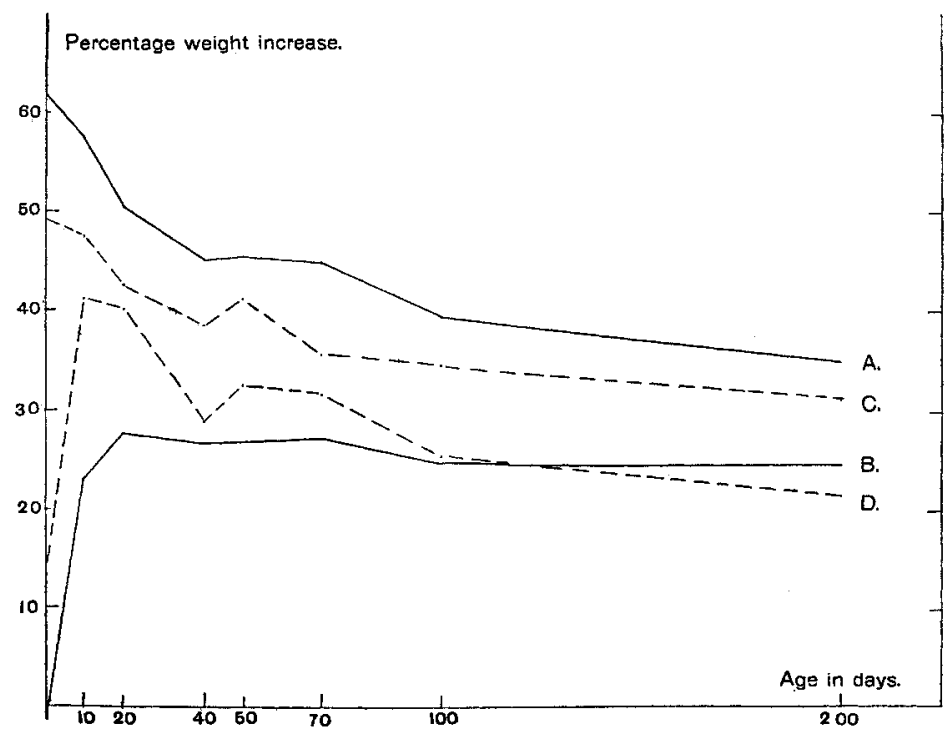

Chart 5 Showing the final percentage weight increase in series of rats' brains kept for four weeks in different quantities of neutralized and of non-neutralized solutions of 4 per cent formaldehyde. A, $40 \mathrm{cc}$. of a neutralized solution used; $B, 40 \mathrm{cc}$. of a non-neutralized solution used; $C, 20 \mathrm{cc}$. of a neutralized solution used; $D, 20 \mathrm{cc}$. of a non-neutralized solution used.

Series 4. As it is known from the experiments of Donaldson ('94), Hrdlicka and others, that the amount of liquid in which brains are kept has a decided effect on the weight increase, the present series of experiments was made to test this point with brains of rats of various ages. The experiments were made exactly like those in Series 3, except that the amount of solution used was reduced from 40 to $20 \mathrm{cc}$. in every case. The data obtained in the experiments in which the brains were kept for four weeks in $20 \mathrm{cc}$. of a neutralized solution are given in table 6 .

A comparison of the data given in this table with that in table 4 shows that the maximum, as well as the average, percentage weight increase is much lower when brains are treated with 20 cc. of solution than when double this amount of solution is used. This is the result one would expect if the amount of swelling diminishes as the strength of the solution is increased; 
for the dilution of the solution by the tissue fluids is greater when a small amount of solution is used, and the effect is then the same as if the brains were kept in a weaker solution. According to the observations of Hrdlicka, the weight increase in brains treated with unneutralized solutions of formaldehyde is "larger with the weakest solutions and decreases as the proportion of formalin increases." It is evident, therefore, that in these experiments some factor, possibly the $\mathrm{NaCO}_{3}$ used in neutralizing the solutions, has checked the swelling action of the weakened solu-

TABLE 6

Percentage weight increase in rats' brains, each kept for four weeks in 20 cc. of a neutralized solution of 4 per cent formaldehyde made fresh for each lot of animals lilled (averages for two brains at each age)

\begin{tabular}{|c|c|c|c|c|c|c|c|c|}
\hline \multirow{2}{*}{ TIME SOLUTION ACTED } & \multicolumn{8}{|c|}{ AGE OF RATS } \\
\hline & $\begin{array}{l}\text { New- } \\
\text { born }\end{array}$ & $\begin{array}{c}10 \\
\text { days }\end{array}$ & $\stackrel{20}{\text { days }}$ & $\begin{array}{c}40 \\
\text { days }\end{array}$ & $\begin{array}{c}50 \\
\text { days }\end{array}$ & $\begin{array}{c}70 \\
\text { days }\end{array}$ & $\begin{array}{l}100 \\
\text { days }\end{array}$ & $\begin{array}{c}200 \\
\text { days }\end{array}$ \\
\hline$I$ day.......... & $54.6^{1}$ & 50.5 & 42.7 & $41.2^{1}$ & $46.6^{2}$ & 39.9 & $40.1^{1}$ & 32.9 \\
\hline 3 days.... & 53.3 & $51.8^{1}$ & $46.4^{1}$ & 40.8 & 44.3 & $42.4^{1}$ & 38.5 & $35.6^{1}$ \\
\hline 7 days. . & 50.1 & 49.9 & 43.3 & 38.7 & 41.4 & 37.5 & 35.3 & 32.3 \\
\hline 2 weeks. & 50.4 & 49.2 & 39.3 & 38.1 & 40.8 & 35.7 & 34.8 & 31.3 \\
\hline 3 weeks.. & 47.9 & 49.5 & 40.6 & 38.7 & 40.5 & 36.0 & 34.3 & 31.0 \\
\hline 4 weeks. . & 49.1 & 47.6 & 42.5 & 38.2 & 41.0 & 35.8 & 34.2 & 31.2 \\
\hline Average percentage gain. & 50.9 & 49.7 & 42.5 & 39.3 & 42.4 & 37.9 & 36.2 & 32.4 \\
\hline
\end{tabular}

1 Maximum weight increase.

tion. This seems probable from the results obtained in the second set of experiments in this series which show that a weak acid solution of formaldehyde causes a greater amount of swelling than does a stronger one.

The final weight changes for the various groups of brains are plotted in the graphs in chart 6 .

Table 7 gives the data obtained in the experiments in which brains of different ages remained for four weeks in 20 cc. of a non-neutralized solution of 4 per cent formaldehyde.

In this instance brains of new-born rats do not show such striking weight changes as are shown in table 5. The initial rise 


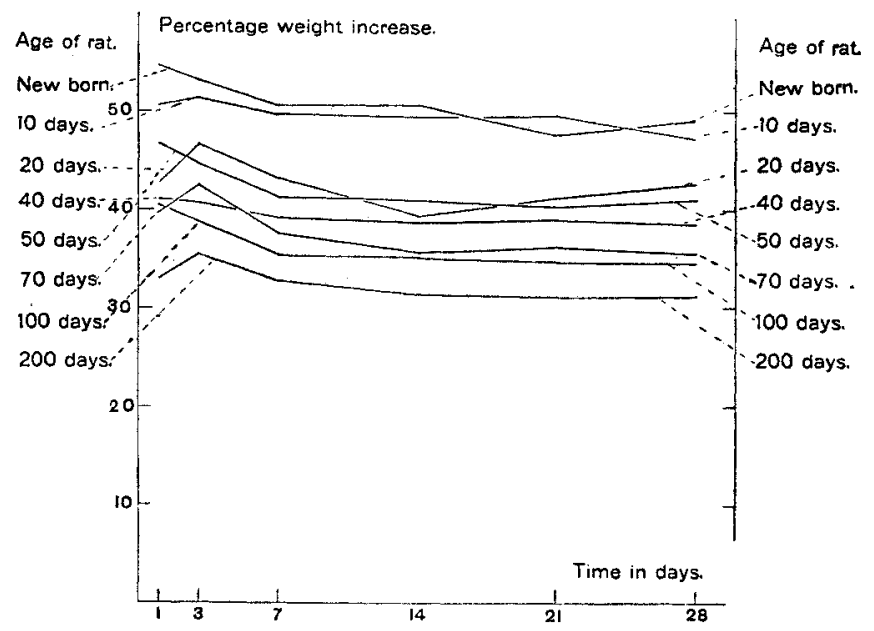

Chart 6 Showing the weight changes in brains of rats of various ages, each kept for four weeks in $20 \mathrm{cc}$. of a neutralized solution of 4 per cent formaldehyde.

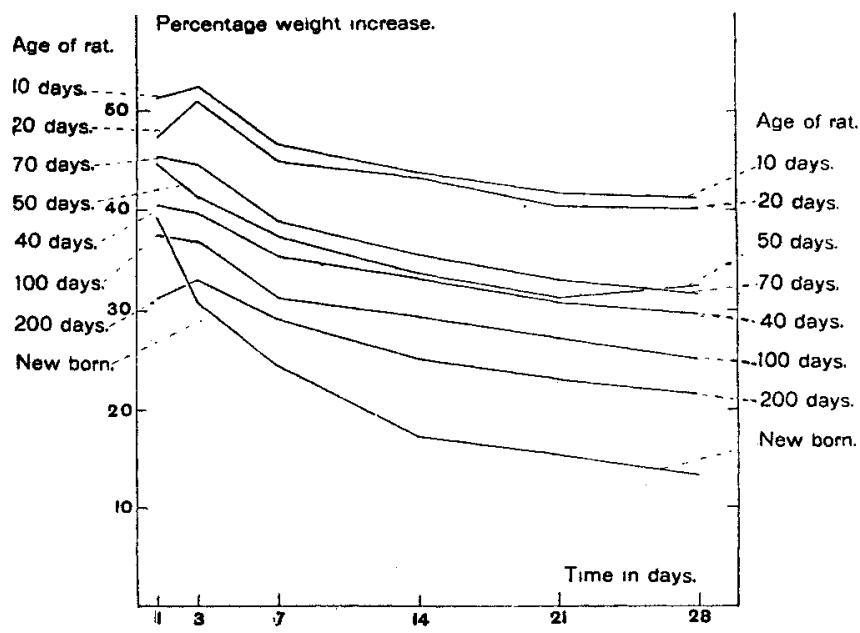

Chart 7 Showing the weight changes in brains of rats of various ages, each kept for four weeks in 20 ce. of a non-neutralized solution of 4 per cent formaldehyde. 
TABLE 7

Percentage weight increase in rats' brains, each kept for four weeks in 20 cc. of a non-neutralized solution of 4 per cent formaldehyde made fresh for each lot of animals killed (averages for two brains at each age)

\begin{tabular}{|c|c|c|c|c|c|c|c|c|}
\hline \multirow{2}{*}{ TIME SOLUTION ACTED } & \multicolumn{8}{|c|}{ AGE OF RATS } \\
\hline & $\begin{array}{l}\text { New- } \\
\text { born }\end{array}$ & $\begin{array}{c}10 \\
\text { days }\end{array}$ & $\begin{array}{c}20 \\
\text { days }\end{array}$ & $\begin{array}{c}40 \\
\text { days }\end{array}$ & $\begin{array}{c}50 \\
\text { days }\end{array}$ & $\begin{array}{c}70 \\
\text { days }\end{array}$ & $\begin{array}{c}100 \\
\text { days }\end{array}$ & $\begin{array}{c}200 \\
\text { days }\end{array}$ \\
\hline 1 day. & $38.9^{1}$ & 51.5 & 47.1 & $40.2^{1}$ & $44.5^{1}$ & $45.1^{1}$ & 37.71 & 31.1 \\
\hline 3 days. . & 31.1 & $52.1^{1}$ & $51.3^{1}$ & 39.9 & 41.3 & 44.8 & 36.9 & $33.1^{\mathrm{i}}$ \\
\hline 7 days.. & 24.2 & 46.5 & 44.9 & 35.2 & 37.4 & 38.6 & 31.4 & 29.2 \\
\hline 2 weeks. & 17.2 & 43.9 & 43.3 & 33.1 & 32.9 & 35.7 & 29.3 & 25.1 \\
\hline 3 weeks. . & 15.5 & 41.9 & 40.4 & 30.7 & 31.5 & 33.7 & 27.1 & 23.2 \\
\hline 4 weeks. . & 13.4 & 41.1 & 40.0 & 28.9 & 32.2 & 31.9 & 25.3 & 21.9 \\
\hline Average percentage gain & 23.4 & 46.1 & 44.6 & 34.7 & 36.6 & 38.3 & 31.3 & 27.3 \\
\hline
\end{tabular}

1 Maximum weight increase.

of 38.9 per cent, found at the end of the first day, is greater by 4 per cent than that found in the previous set of experiments, but the subsequent fall in weight is not so rapid and at the end of four weeks the brains still weigh an average of 13.4 per. cent above the original weight and therefore do not appear to have lost any of their substance. In these experiments the greatest percentage gain in weight occurs in the brains of the ten-day and twenty-day-old animals, the average gain for the entire period over which the weighings extended being in each case more than 40 per cent of the fresh weight: the data for the brains of animals from 40 to 200 days old differ but slightly from the corresponding data in table 5 . The weight changes in the groups of brains of different ages are plotted in chart 7 .

The contrast between the results of this series of experiments and those of Series 3 is brought out sharply in chart 5. Graph $C$ was plotted from the final weights of the brains kept in 20 cc. of a neutralized solution of 4 per cent formaldehyde; graph $D$ was plotted from data obtained where $20 \mathrm{cc}$. of a non-neutralized solution was used. These graphs run, for the most part, between the graphs $A$ and $B$, which were plotted from the final brain 
weights given in tables 4 and 5 . Where the solutions were neutralized the form of the graphs is practically the same whether 40 or $20 \mathrm{cc}$. of the solution was used, but graph $C$ falls considerably below graph $A$ at every point. Where the solutions were not neutralized the form of the graphs show more variation, but graph $D$, for most of its length, runs higher than graph $B$. Since the diluent action of the tissue fluids is undoubtedly greater when 20 instead of $40 \mathrm{cc}$. of solution is used, it is evident that a stronger neutralized solution of 4 per cent formaldehyde causes more swelling in brain tissue than does a weaker neutralized solution, whereas the reverse is the case where the solutions are not neutralized.

Series 5. Since the temperature at which a solution acts is known to have a marked effect on the rate at which the solution will be absorbed, a final series of experiments was made to ascertain how different temperatures would affect the swelling of rats' brains in 4 per cent formaldehyde. In all of these experiments each brain was put into $40 \mathrm{cc}$. of a solution that was freshly made and neutralized when wanted for use. The bottles containing one set of brains were kept in a water bath at a constant temperature of $36^{\circ} \mathrm{C}$. for four weeks: the corresponding set of brains remained at a temperature of 8 to $11^{\circ} \mathrm{C}$. for the same length of time.

The data for the brains kept at the higher temperature are given in table 8.

In these experiments, as shown in the table, the maximum weight increase was reached in every case at the end of the first day. The decrease in weight at three days was practically the same for the brains of all ages, amounting to about 8 per cent. Subsequent weight changes were comparatively slight and, except in the very young brains, the final weighings differed but little from those noted for the third day. In this instance, also, there is a direct relation between the age of the animals and the percentage increase in brain weight, but the average percentage gain for the entire set of brains is considerably less than that found in the experiments in which the brains were kept in a neutralized solution at room temperature (table 4). These results accord 
TABLE 8

Percentage weight increase in rats' brains, each left for four weeks in $40 \mathrm{cc}$. of a neutralized solution of 4 per cent formaldehyde kept at a constant temperature of $36^{\circ} \mathrm{C}$. (averages for two brains at each age)

\begin{tabular}{|c|c|c|c|c|c|c|c|c|}
\hline \multirow{2}{*}{ TIME SOLUTION ACTED } & \multicolumn{8}{|c|}{ AGE OF RATS } \\
\hline & $\begin{array}{l}\text { New- } \\
\text { bcrn }\end{array}$ & $\begin{array}{c}10 \\
\text { days }\end{array}$ & $\stackrel{20}{\text { days }}$ & $\begin{array}{c}40 \\
\text { days }\end{array}$ & $\begin{array}{c}50 \\
\text { days }\end{array}$ & $\begin{array}{c}70 \\
\text { days }\end{array}$ & $\begin{array}{c}100 \\
\text { days }\end{array}$ & $\begin{array}{c}200 \\
\text { days }\end{array}$ \\
\hline $1 \mathrm{day} .$. & $61.5^{1}$ & $59.5^{1}$ & $50.9^{1}$ & $51.8^{1}$ & $45.5^{1}$ & $44.3^{1}$ & $39.3^{1}$ & $38.8^{1}$ \\
\hline 3 days. & 53.6 & 51.6 & 42.9 & 43.9 & 37.8 & 36.6 & 31.7 & 32.7 \\
\hline 7 days.. & 48.3 & 49.6 & 43.6 & 43.2 & 37.4 & 36.5 & 31.1 & 30.4 \\
\hline 2 weeks. & 50.4 & 48.4 & 43.7 & 44.7 & 38.1 & 36.9 & 32.8 & 31.6 \\
\hline 3 weeks.. & 42.3 & 47.8 & 44.2 & 44.8 & 38.6 & 38.8 & 32.4 & 31.5 \\
\hline 4 weeks..... & 40.6 & 48.3 & 45.0 & 44.8 & 38.2 & 39.3 & 33.3 & 32.6 \\
\hline Average percentage gain. & 49.1 & 50.9 & 45.0 & 45.5 & 39.3 & 38.7 & 33.4 & 32.9 \\
\hline
\end{tabular}

${ }^{1}$ Maximum weight increase.

with Donaldson's ('94) observations that brains of sheep kept in a 2 per cent solution of bichromate of potassium at a temperature of $38^{\circ} \mathrm{C}$. attain their maximum weight at a very early period and gain relatively less than when kept at a temperature of 10 to $17^{\circ} \mathrm{C}$. In the case of the rats' brains kept at a temperature of $36^{\circ} \mathrm{C}$. the decrease in the amount of swelling can be attributed, in part at least, to the fact that this temperature partially decomposes the solution of formaldehyde and liberates a considerable amount of formaldehyde gas. This of course weakens the solution, and a weaker solution of formaldehyde that has been neutralized with $\mathrm{NaCO}_{3}$ does not cause as much swelling in rats' brains as does a stronger one, as was shown in the experiments in Series 4.

Graphs for the weight changes in the various sets of brains kept at a temperature of $36^{\circ} \mathrm{C}$. are shown in chart 8 . All of these graphs, it may be noted, are grouped in pairs according to the age of the animals. While a paired arrangement of some of the graphs is to be found in other charts $(6,7$ and 9$)$, in no case is the phenomenon as marked as in chart 8 . 


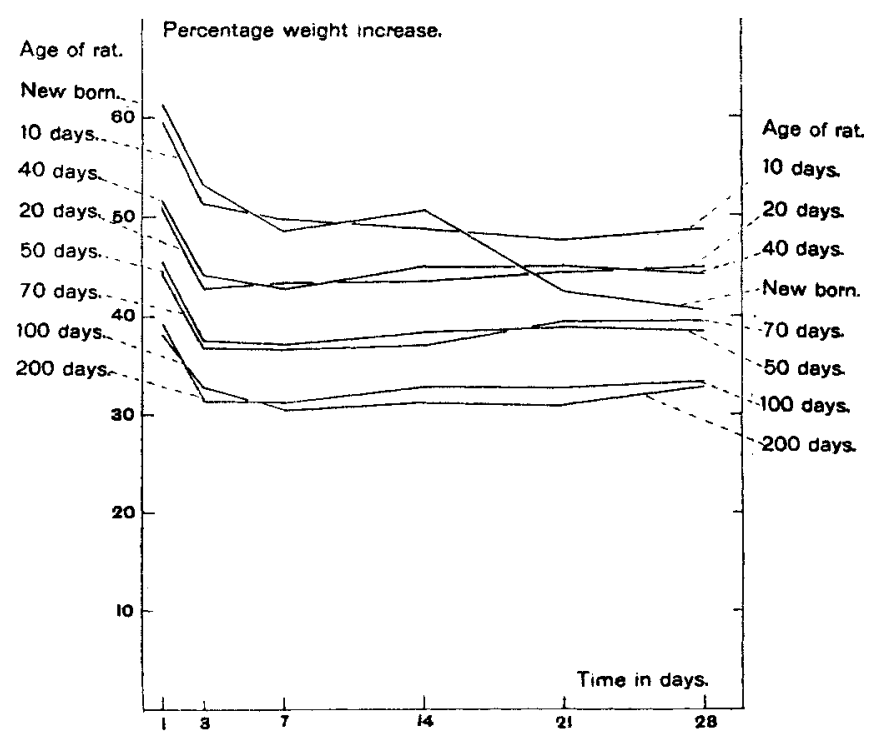

Chart 8 Showing the weight changes in brains of rats of various ages, each remaining for four weeks in $40 \mathrm{cc}$. of a neutralized solution of 4 per cent formaldehyde kept at a constant temperature of $36^{\circ} \mathrm{C}$.

Table 9 gives the data for the weight changes in the brains kept in 4 per cent formaldehyde for four weeks at a temperature of 8 to $11^{\circ} \mathrm{C}$.

As indicated in table 9, the maximum weight increase in all sets of brains was attained on the third day except in the case of the brains of the new-born rats where, as in most of the previous experiments, the maximum increase comes at the end of the first day. The subsequent loss in weight is very slight and it does not amount in any case to more than 8 per cent of the original brain weight. While the brains of young rats (birth to 40 days) show a relatively greater weight increase than the brains of older animals, there is not the very uniform decrease with advancing age that was noted in the previous set of experiments (table 4) where the brains were kept in 40 cc. of a neutralized solution at ordinary room temperature (about $20^{\circ} \mathrm{C}$.), neither is the average increase for the various groups of brains as high. 
TABLE 9

Percentage weight increase in rats' brains, each left for four weeks in $40 \mathrm{cc}$. of a neutralized solution of 4 per cent formaldehyde kept at a temperature of 8 to $11^{\circ} \mathrm{C}$. (averages for two brains at each age)

\begin{tabular}{|c|c|c|c|c|c|c|c|c|}
\hline \multirow{2}{*}{ TMME BOLUTION ACTED } & \multicolumn{8}{|c|}{ AGE OF RATS } \\
\hline & $\begin{array}{l}\text { New- } \\
\text { born }\end{array}$ & $\begin{array}{c}10 \\
\text { days }\end{array}$ & $\underset{\text { days }}{20}$ & $\begin{array}{c}40 \\
\text { days }\end{array}$ & $\begin{array}{c}50 \\
\text { days }\end{array}$ & $\begin{array}{c}70 \\
\text { days }\end{array}$ & $\begin{array}{c}100 \\
\text { days }\end{array}$ & $\begin{array}{c}200 \\
\text { days }\end{array}$ \\
\hline 1 day..... & 55.91 & 41.6 & 37.3 & 38.0 & 31.3 & 36.7 & 30.9 & 30.8 \\
\hline 3 days... & 51.6 & $53.8^{1}$ & $43.6^{1}$ & $48.3^{1}$ & $34.0^{1}$ & $37.0^{1}$ & 31.5 i & $33.4^{1}$ \\
\hline 7 days.... & 49.3 & 48.8 & 42.9 & 40.4 & 31.1 & 34.3 & 28.4 & 31.1 \\
\hline 2 weeks. & 50.7 & 48.0 & 38.7 & 40.1 & 30.3 & 33.8 & 28.7 & 29.6 \\
\hline 3 weeks. & 47.9 & 47.7 & 39.2 & 40.4 & 29.9 & 33.7 & 27.4 & 29.2 \\
\hline 4 weeks. & 47.9 & 45.7 & 38.9 & 40.4 & 30.0 & 33.5 & 27.9 & 28.4 \\
\hline Average percentage gain & 50.6 & 47.6 & 40.1 & 41.3 & 31.1 & 34.7 & 29.1 & 30.4 \\
\hline
\end{tabular}

${ }^{1}$ Maximum weight increase.

This latter result is what might be expected, since a low temperature tends to lessen the amount of absorption of a liquid by brain tissue. This is the only set of experiments in which the average gain in the brains of adult rats is greater than that in the brains of 100-day-old animals. The increase, however, amounts to only about 1 per cent, so it is probably merely a chance variation.

Chart 9 shows the graphs plotted for the weight changes in the brains kept at a low temperature. There is a tendency here also to a paired arrangement of the graphs according to age, but it is not as pronounced as in chart 8 .

The final percentage gain in weight for the two sets of brains used in this series of experiments is shown by graphs in chart 10. The form of the graphs is much the same, but the graph for the brains kept at relatively high temperature $(A)$ runs somewhat higher than that for the brains kept at a low temperature $(B)$. A difference of $25^{\circ} \mathrm{C}$. in the temperature of the solutions in which the brains are kept has but comparatively little effect on the final weight increase at the end of four weeks 


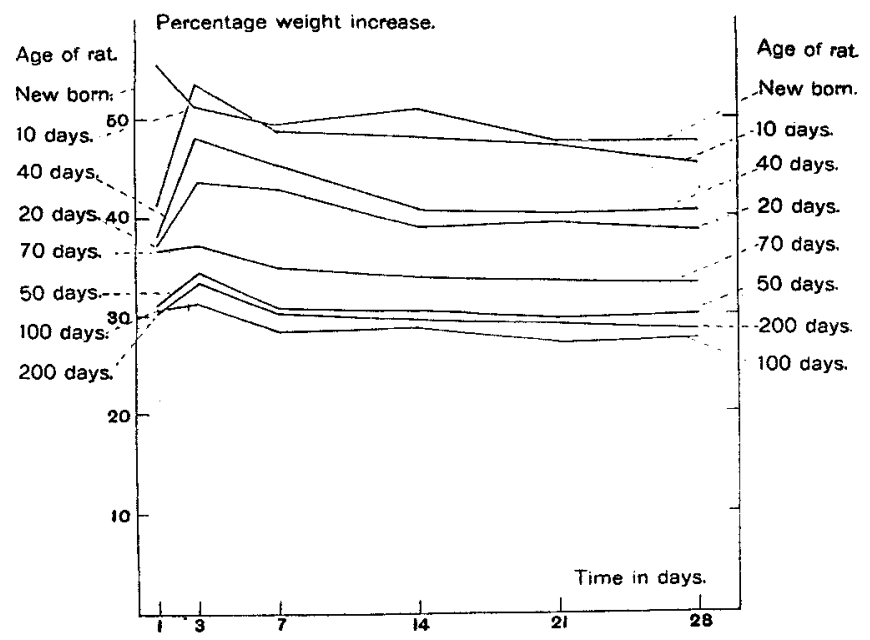

Chart 9 Showing the weight changes in brains of rats of various ages, each remaining for four weeks in $40 \mathrm{cc}$. of a neutralized solution of 4 per cent formaldehyde kept at a temperature of 8 to $11^{\circ} \mathrm{C}$.

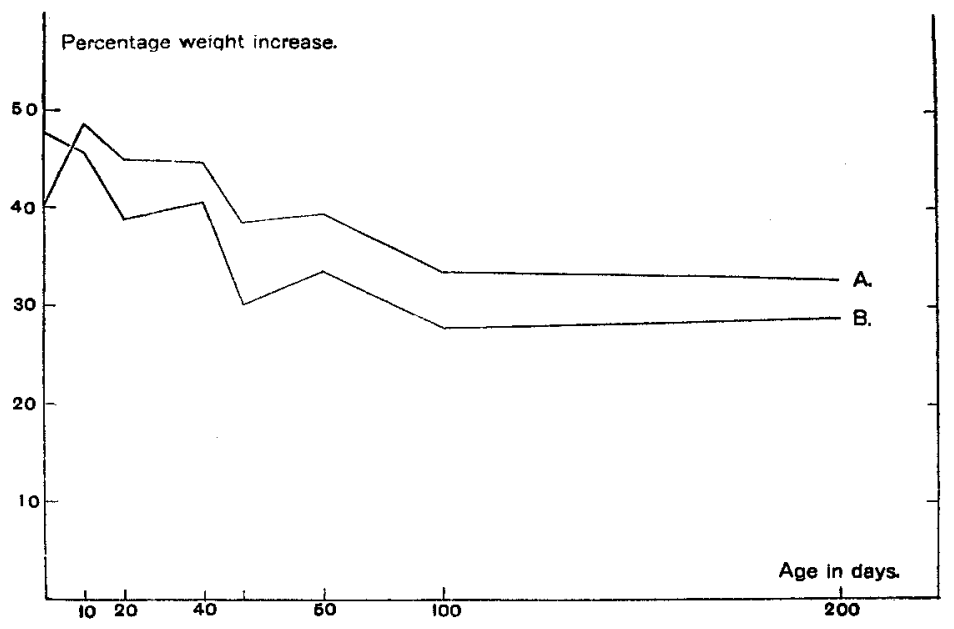

Chart 10 Showing the final percentage weight increase in two series of rats brains kept at different temperatures during the four weeks they remained in a neutralized solution of 4 per cent formaldehyde. $A$, solutions kept at a temperature of $36^{\circ} \mathrm{C}$.; $B$, solutions kept at a temperature of 8 to $11^{\circ} \mathrm{C}$. 
THE EFFECTS OF 4 PER CENT FORMALDEHYDE ON THE PERCENTAGE OF SOLIDS IN THE BRAIN OF THE ALBINO RAT

All the brains used in the above series of experiments, with the few exceptions that will be noted later, were heat dried for one week at the end of the weighing period to obtain the amount of dry substance. The percentage of solids left in the brains after treatment with the formaldehyde solutions was then calculated from the weight of the brains when fresh. A summary of the results obtained for the brains of each age is given in table 10. This table shows also the normal percentage of solids in the brains of rats of various ages as deduced from data given by Donaldson ('10) in his paper, "On the percentage of water in the brain and in the spinal cord of the albino rat."

As shown in this table, the normal percentage of solids in the brain of the rat, as deduced from Donaldson's data, varies directly with the age of the animal, being 12.2 per cent of the total brain weight in new-born rats and 21.6 per cent in the brains of adults. The computations made for the brains used in these various series of experiments show that in every case the percentage of solids is less than that normally found in fresh brains at the age observed, and that it increases from birth to maturity in a regularly striking manner. It follows from this that formaldehyde solutions extract some of the solids from the brain tissues. Brains of new-born rats suffer the greatest loss of solids; brains of adults are least affected.

The amount of solids lost from the brain of the rat through the, action of a formaldehyde solution is not directly correlated either with the age of the animal or with the size of the brain. Brains of very young animals (birth to 10 days) lose about 30 per cent of their solids after treatment with a solution of formaldehyde. The average loss from the brains of older animals falls from 7.4 per cent in the 20-day-old brains to 1.5 per cent in the brains of animals 40 days of age. In brains of 50-day-old rats there is an increase in the extraction of solids by formaldehyde amounting to 6.2 per cent. The relative loss of solids from the brains of 40- and of 50-day-old animals, as shown in table 10, is not due to exceptional records for certain rats at these ages, 
but it is found in practically all the individual records for all series of experiments. An examination of the data given in tables 1 to 9 shows that in six cases the average weight increase in the brains of the 50-day-old rats is greater than that in the brains of 40-day animals. These facts seem to indicate that some chemical change takes place in the brain at 50 days of age that has not been brought out by any analysis so far made.

TABLE 10

The percentage of solids in brains of rats of various ages kept from four to eighteen weeks in solutions of 4 per cent formaldehyde (computations made from original brain weights)

\begin{tabular}{|c|c|c|c|c|c|c|c|c|}
\hline \multirow{2}{*}{ EXPERMMENTB } & \multicolumn{8}{|c|}{ AGE OF RATS } \\
\hline & $\begin{array}{l}\text { New- } \\
\text { born }\end{array}$ & $\begin{array}{c}10 \\
\text { days }\end{array}$ & $\stackrel{20}{\text { days }}$ & $\begin{array}{c}40 \\
\text { days }\end{array}$ & $\begin{array}{c}50 \\
\text { days }\end{array}$ & $\begin{array}{c}70 \\
\text { days }\end{array}$ & $\begin{array}{c}100 \\
\text { days }\end{array}$ & $\begin{array}{c}200 \\
\text { days }\end{array}$ \\
\hline $\begin{array}{l}\text { Brains kept } 18 \text { wks. in neu- } \\
\text { tralized stock solutions.... }\end{array}$ & 8.1 & 10.3 & 14.7 & 18.4 & 19.4 & 19.5 & & 20.9 \\
\hline $\begin{array}{c}\text { Brains kept } 10 \text { wks. in sol. } 5 \\
\text { mos. old................... }\end{array}$ & 8.1 & 10.1 & 16.5 & 19.4 & 19.4 & 20.5 & 19.7 & 20.5 \\
\hline $\begin{array}{l}\text { Brains kept } 10 \text { wks. in freshly } \\
\text { made sol.................... }\end{array}$ & 7.8 & 10.3 & 16.0 & 19.2 & 19.5 & 20.1 & 20.1 & 21.6 \\
\hline $\begin{array}{l}\text { Brains kept } 4 \text { wks. in } 40 \mathrm{cc} . \\
\text { neutral sol.................... }\end{array}$ & 8.2 & 10.1 & 16.4 & 19.3 & 19.6 & 19.6 & 20.9 & 21.8 \\
\hline $\begin{array}{l}\text { Brains kept } 4 \text { wks. in } 40 \mathrm{cc} \\
\text { acid sol................ } \\
\text { Brains kent } 4 \text { wks in } 20 \mathrm{cc}\end{array}$ & 9.6 & 10.9 & 16.7 & 19.3 & 19.1 & 20.7 & 20.1 & 21.1 \\
\hline neutral sol....................... & 9.2 & 9.8 & 16.2 & 19.7 & 20.5 & 19.9 & 20.2 & 21.5 \\
\hline $\begin{array}{l}\text { Brains kept } 4 \text { wks. in } 20 \mathrm{cc} \text {. } \\
\text { acid sol.................... }\end{array}$ & 10.5 & 10.9 & 16.3 & 19.0 & 20.0 & 20.1 & 20.8 & 21.6 \\
\hline $\begin{array}{l}\text { Brains kept } 4 \text { wks. in neutral } \\
\text { sol. at temp. } 26^{\circ} \mathrm{C} \ldots \ldots \ldots . \\
\text { Brains kept } 4 \text { wks in neutral }\end{array}$ & 9.7 & 9.8 & 15.1 & 18.7 & 19.4 & 19.8 & 20.1 & 20.1 \\
\hline sol. at temp. 8 to $11^{\circ} \mathrm{C} \ldots \ldots$ & 8.3 & 10.6 & 16.3 & 19.2 & 19.0 & 20.1 & 20.1 & 21.7 \\
\hline Averages for above series. & 8.6 & 10.6 & 16.3 & 19.2 & 19.6 & 20.1 & 20.3 & 21.2 \\
\hline $\begin{array}{r}\text { Normal percentage of solids } \\
\text { in rats' brains (Donaldson) }\end{array}$ & 12.2 & 14.6 & 17.5 & 19.5 & 20.9 & 21.1 & 21.3 & 21.6 \\
\hline 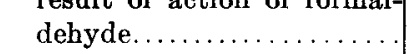 & 29.5 & 29.4 & 7.4 & 1.5 & 6.2 & 4.7 & 4.7 & 1.8 \\
\hline
\end{tabular}


Brains of 70- and of 100-day-old rats suffer about the same relative loss in substance when kept in a 4 per cent solution of formaldehyde, amounting to about 5 per cent. The extraction from adult brains is about 2 per cent, showing that formaldehyde has little solvent action on the brains at this stage.

THE EFFECTS OF A 4 PER CENT SOLUTION OF FORMALDEHYDE ON THE BRAINS OF RATS INFECTED WITH PNEUMONIA

In the course of a study of the effects of pneumonia on the brain of the rat (King '11) a small series of experiments was made to ascertain whether the brains of animals suffering with this disease would react as do the brains of healthy rats when placed in a 4 per cent solution of formaldehyde. Five adult rats which were in advanced stages of pneumonia were killed with ether, and the brains removed at once and weighed. Each brain was placed in $40 \mathrm{cc}$. of a stock solution of 4 per cent formaldehyde which had been neutralized with $\mathrm{NaCO}_{3}$. The brains were kept in the solutions for one week, then weighed and the percentage weight increase calculated. For control purposes brains of five adult rats that were not suffering from any disease as far as could be determined were treated in a similar manner. The exact age of the rats used in these experiments was not known in any case, but all the rats were from five to eight months old. The age of the animal, therefore, was not a factor that could have had any appreciable influence on the results. Table 11 shows the fresh brain weights of the control and of the infected animals together with the percentage weight increase at the end of one week.

As shown in table 11, the average fresh brain weight as well as the percentage weight increase after treatment with 4 per cent formaldehyde are practically the same for both groups of brains used in this series of experiments. It would seem, therefore, as if pneumonia, even in its advanced stages, does not produce any changes in the brain tissues that affect the amount of swelling of the brains when kept in a solution of formaldehyde. An exarnination of the individual records, however, point to a dif- 
ferent conclusion. The lowest brain weight in the infected group is $1.5915 \mathrm{gms}$. This weight is exceptionally low for the brain of an adult rat and it is about that found in a healthy rat of 50 days of age, as may be seen from table 12. The rat in question, therefore, was probably a 'runt' and cannot properly be classed with animals of normal size.

TABLE 11

\begin{tabular}{|c|c|c|c|c|}
\hline & \multicolumn{2}{|c|}{ CONTROL ANIMALS. } & \multicolumn{2}{|c|}{ INFECTED ANIMALS } \\
\hline & $\begin{array}{c}\text { Fresh } \\
\text { brain welght } \\
\text { In grams }\end{array}$ & $\begin{array}{c}\text { Percentage } \\
\text { weight increase } \\
\text { after one week } \\
\text { In } 4 \text { per cent } \\
\text { formaldehyde }\end{array}$ & $\begin{array}{l}\text { Fresh } \\
\text { brain welght } \\
\text { in grams }\end{array}$ & $\begin{array}{c}\text { Percentage } \\
\text { weight increase } \\
\text { after one week } \\
\text { in } 4 \text { per cent } \\
\text { formaldehyde }\end{array}$ \\
\hline & 1.7335 & 37.85 & 1.5915 & 24.53 \\
\hline & 1.7501 & 36.47 & 1. 7612 & 36.34 \\
\hline & 1.7671 & 35.08 & 1.7917 & 40.44 \\
\hline & 1.7867 & 39.34 & 1.8072 & 43.81 \\
\hline & 1.8471 & 46.60 & 1.8889 & 48.08 \\
\hline Average of above records. & 1.7769 & 39.05 & 1.7681 & 38.64 \\
\hline Average of last four records & 1.7887 & 39.38 & 1.8122 & 42.18 \\
\hline
\end{tabular}

TABLE 12

Normal brain weights of albino rats of various ages and derived from data given by Donaldson ('08, '09)

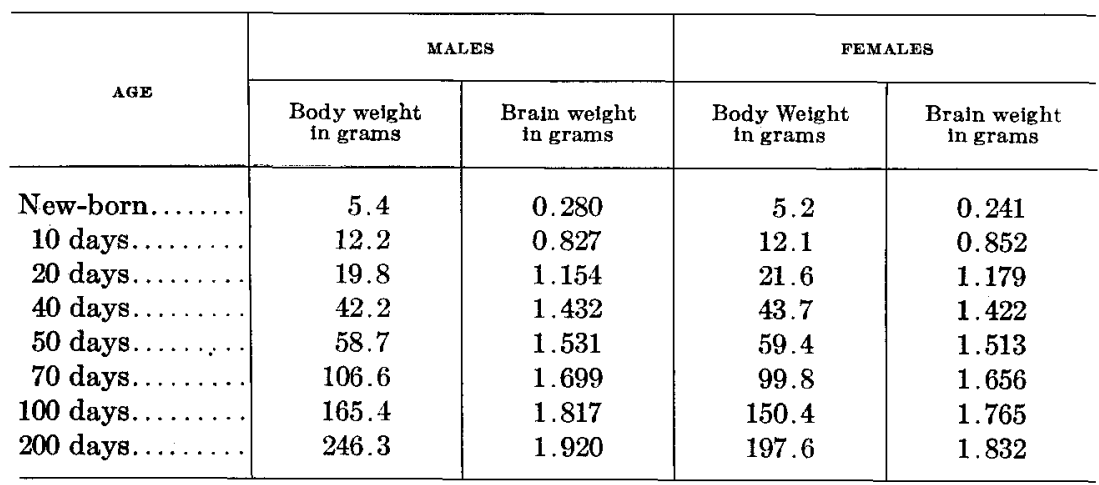


If we omit from table 11 the lowest record, both for the control and for the infected group, the remaining brain weights come fairly within the limits of probable normal variation in the brain weight of adult rats, as indicated in table 12 . With this modification in table 11, the brains of the infected animals are, on the whole, slightly heavier than those of the controls, and the average percentage weight increase in these brains after treatment with 4 per cent formaldehyde is 2.80 per cent greater than that in the control group. Comparing the percentage weight increase in the brain of each of the infected animals with that of the control of the nearest brain weight, it is found that in every case the percentage weight increase in the brain of the infected animal is somewhat greater than that in the brain of the normai animal. It has been shown that the brain of an animal infected with pneumonia contains from 0.4 per cent to 0.5 per cent less water than the brain of healthy animals of about the same age (King '11). Pneumonia, therefore, not only decreases the percentage of water in the brain of the rat, but it also produces changes which cause the brain to undergo a slightly greater percentage weight increase when subjected to the action of a 4 per cent formaldehyde.

The greater percentage weight increase in the brains of the infected group of animals is not due to the fact that the brains of these animals were larger than those of the controls. In animals of the same age there is often a considerable variation in the brain weight, due to the fact that large animals have heavier brains than do smaller ones. An examination of the records of the 69 sets of brains of various ages used in these different series of experiments show that in 34 cases only does the larger brain undergo a greater percentage weight increase in 4 per cent formaldehyde. It is the age of the animal, not the size of the brain, that is a factor in determining the amount of swelling that the brain will undergo in a solution of formaldehyde. 
THE HISTOLOGICAL EFFECTS OF FORMALDEHYDE ON THE BRAIN OF THE ALBINO RAT

The histological changes produced in the cell structures of the brain of the albino rat by various formaldehyde solutions have been described in a previous paper (King '10). In general, as therein stated, such solutions "give a good fixation of the cell body, but they tend to produce a swelling of the nucleus which is usually accompanied by a poor preservation of the nuclear contents." In order to determine whether the conditions which so appreciably affect the amount of swelling of brain tissue in 4 per cent formaldehyde also produce histological changes in the cell structures, preparations were made of some of the brains of 100-day-old rats used in the experiments described above. After their final weighing at the end of a stated period, these brains were transferred into alcohol and imbedded and stained in the manner recommended in a previous paper (King '10). A careful examination was then made of the large cells in the cerebral cortex at the level of the optic chiasma.

In a brain that had been subjected to the action of 40 cc. of a neutralized solution of formaldehyde for four weeks the cell outlines were clearly defined, but somewhat irregular; the nuclei, however, were greatly distended and the nuclear contents were badly preserved. In many cases, also, the cytoplasm appeared vacuolated. In a brain kept in $40 \mathrm{cc}$. of a non-neutralized solution for four weeks, the nuclei appeared fully as much swollen as in the previous case, but the chromatin contents were far better preserved; the cell outlines stained more sharply and were somewhat more regular; and the cytoplasm was not vacuolated. Where the amount of solution used was reduced to $20 \mathrm{cc}$., the fixation of the cell structures, both in the brain that had been kept in a neutralized solution and in the one that had been subjected to the action of a slightly acid solution, the fixation of the cells was about the same as when double the amount of solution had been used. For histological preparations of brain structure, therefore, a neutralized solution of formaldehyde does not, apparently, have the advantage claimed by Bayon, for it greatly 
increases the amount of swelling of the brain and has a correspondingly bad effect on the cell structures.

Keeping the formaldehyde solution at a temperature of $36^{\circ} \mathrm{C}$. produces marked changes in the entire brain. By the third day the brains have a soft, gelatinous appearance which is not found in brains kept in a solution of formalin at room temperature or below. Preparations of these brains are practically useless for histological purposes, as the nuclei are greatly distorted and only faint traces of chromatin can be detected. A brain kept in a neutralized solution at a temperature of 8 to $11^{\circ} \mathrm{C}$. for four weeks shows a fixation of the cell structures about like that obtained when the solution remains at laboratory temperature, but the cell outlines are sharper and the cell contents stain much better.

It is evident, from the results of these investigations, that conditions which affect the amount of swelling of brains in 4 per cent formaldehyde also affect the preservation of the cell structures in the brain tissue. If, therefore, it is considered necessary or advisable to preserve brains in formalin, the solution should not be neutralized and it should be used at relatively low temperature. This will insure a minimum amount of swelling and permit good staining. A prolonged immersion in the solution is unnecessary and decidedly injurious to the tissue cells. If the brain is ever to be used for histological purposes it should be transferred into alcohol as soon as it is fixed and hardened. Nerve tracts are apparently not adversely affected by a formaldehyde solution, and material so preserved can be stained by the Weigert method and used for investigations on the extent of medullation or of degeneration. A solution that swells brains from 30 to 60 per cent of their original weight in three days is obviously not an ideal cell fixative, and brain tissue preserved in formalin is therefore unfit for cytological work. It is more trouble, perhaps, to fix brains in Bouin's ('97) fluid or in the solution of Ohlmacher ('97), both of which give very excellent preparations of cell structures (King '11), but the superiority of these fixatives over a simple aqueous solution of formaldehyde cannot be questioned. 


\section{SUMMARY}

1. A 4 per cent solution of formaldehyde causes a pronounced swelling in the brains of rats of all ages.

2. A solution of formaldehyde undergoes some chemical change on standing, since a solution five months old causes less swelling in the brain of the rat than does a freshly made solution.

3. A 4 per cent solution of formaldehyde neutralized with $\mathrm{NaCO}_{3}$ produces a much greater amount of swelling in the brain of the rat than does a solution that has a faintly acid reaction.

4. A strong neutralized solution of formaldehyde causes a greater percentage weight increase in the rat's brain than does a weak neutralized solution. A reverse result is obtained when the solutions are not neutralized.

5. If rats' brains are subjected to the action of a solution of formaldehyde that is kept at a constant temperature of $36^{\circ} \mathrm{C}$., they undergo a greater amount of swelling than is produced when the solution is kept at a temperature of 8 to $11^{\circ} \mathrm{C}$. The maximum weight increase in the brains is reached by the end of the first day in the former case, and not until the third day in the latter case.

6. When the conditions under which the solution acts are uniform, the maximum weight increase in rats' brains subjected to the action of a 4 per cent solution of formaldehyde is attained in all cases by the third day, and there is then a gradual decrease in weight. Brains of very young animals tend to reach the maximum earlier than do those of older animals.

7. The percentage weight increase in rats' brains as the result of the action of a 4 per cent formaldehyde solution tends to be greater in the brains of young animals than in those of adults.

8. In animals of the same age the larger brain does not show a greater percentage weight increase after treatment with a solution of formaldehyde than does the smaller one. 
9. A 4 per cent solution of formaldehyde extracts solids from the brains of rats of all ages. This is shown by the fact that the percentage of solids in brains that have been subjected to the action of such a solution is always less than that found in the fresh brains of animals of the same age. Brains of very young rats lose much more of their solids than do brains of older animals.

10. Brains of animals infected with pneumonia show a slightly greater percentage weight increase when treated with a 4 per cent solution of formaldehyde than do the brains of healthy animals.

11. Even under the most favorable conditions an aqueous solution of formaldehyde is not a satisfactory fixative for the cell structures in brain tissues, as it causes a pronounced distention of the nuclei and gives a poor preservation of the nuclear contents.

\section{LITERATURE CITED}

Bayon, P. G. 1905 Die histologischen Untersuchungs-Methoden des Nerven systems. Würzburg.

BLom, F. 1893 Der Formaldehyd als Härtungsmittel. Zeitschr. wiss. Mikr., Bd. 10.

Böpecker, C. F. 1908 Zur doppelten Einbettung in Celloidin und Paraffin. Zeitschr. wiss. Mikr., Bd. 25.

Bourn, P. 1897 Phénomènes cytologique anormaux dans l'histogénèse et l'atrophie expérimentale du tube seminfère. Arch. Anat. mikr., T. 1.

Donaldson, H. H. 1894 Preliminary observations on some changes caused in the nervous tissues by reagents commonly employed to harden them. Jour. Morph., vol. 9.

1908 A comparison of the albino rat with man in respect to the growth of the brain and of the spinal cord. Jour. Comp. Neur., vol. 18.

1909 On the relation of the body length to the body weight and to the weight of the brain and of the spinal cord in the albino rat. Jour. Comp. Neur., vol. 19.

1910 On the percentage of water in the brain and in the spinal cord of the albino rat. Jour. Comp. Neur., vol, 20.

Fr ㅍ, P. A. 1895 The use of formalin in neurology. Proc. Amer. Micr. Soc., vol. 17. 
Hermann, F. 1893 Notiz über die Anwendung des Formalins (Formaldehyds: als Härtungs- und Conservirungsmittel. Anat. Anz., B. 9.

HrduickA, A. 1906 Brains and brain preservatives. Proc. U. S. Nat. Museum, vol. 30.

King, Helen Dess 1910 The effects of various fixatives on the brain of the albino rat, with an account of a method of preparing this material for a study of the cells in the cortex. Anat. Record, vol. 4.

1911 The effects of pneumonia and of post mortem changes on the percentage of water in the brain of the albino rat. Jour. Comp. Neur., vol. 21.

LEe, A. B. 1905 The microtomist's vade mecum. Sixth edition, Philadelphia.

Orlmacher, A. P. 1897 A modified fixing fluid for general histological and neuro-histological purposes. Jour. Exper. Med., vol. 11.

Watson, J. B. 1903 Animal education. Univ. Chicago press. 